\title{
Mobile technologies in physics education in Latvian secondary schools
}

\author{
Loreta Juskaite $^{1}$, Aleksandrs Ipatovs ${ }^{2}$, Atis Kapenieks ${ }^{3}$ \\ ${ }^{1}$ Distance Education Study Centre, Riga Technical University \\ ${ }^{2}$ Faculty of Electronics and Telecommunications, RigaTechnical University \\ ${ }^{3}$ Distance Education Study Centre, RigaTechnical University
}

\section{Article Info}

Received Dec 15, 2018

\section{Keyword:}

Mobile technologies

Skills

Knowledge

Teaching/Learning process

\begin{abstract}
The availability of ICT has raised the issue of meaningful use of Mobile technologies (smartphones, tablets, sensors, data loggers, data collectors, as well as other devices and options) in the teaching/learning process of physics to deepen the students' knowledge and develop their research skills. Mobile technologies are constantly and rapidly evolving, and there is practically no social domain where they are not used, including education. Thus, the acquisition of mobile technology usage skills is an integral part of the learning process in a modern school. Education experts are now emphasizing not only the integration of Mobile technologies into the learning process but also the need to improve the efficiency of the learning process for both teachers and students. Success is based not only on what or how much one knows, but also on one's ability to think and act creatively. Mobile technology-based learning process is based on the Educational Technology Competency Standards for Teachers and accentuates the demand for improving teachers' technology skills and with a focus on knowledge and capacity building.

This paper summarizes the research on the use of Mobile technologies in teaching physics in Latvia for the last nine years, as well as analyses the issues and suggestions for improving the process. A pedagogical experiment is conducted based on pre-planned and prepared participation in the learning process.
\end{abstract}

\section{Corresponding Author:}

Loreta Juskaite,

Distance Education Study Centre,

Riga Technical University,

1 Kronvalda Boulevard, Riga, LV-1010, Latvia.

Email: Loreta.Juskaite@rtu.lv

\section{Introduction}

The focus is on the universal soldiers - the teachers, and their work environments - education institutions. In this technological age, solutions are easily accessible. It is possible to observe and instantly evaluate the performance of the whole class and each student individually, and the control of the available content, as well as the users, is essential [1]. The challenge here is the introduction of a learning-based solution for achieving goals and choosing the right mobile technologies, as well as developing a complex technology-based environment to support and enhance the learning process. The aim of physics as a subject in general secondary education is "to deepen the understanding of physical processes in nature and technology, to improve the research skills and to promote the students' co-responsible attitude towards sustainable public development" [2], [3]. Various experts predict which technologies will be the most relevant in education in 
the future [4], and it is the mobile technologies that open the window for a new kind of learning and performance support, providing access to information, processes, and communication anytime and anywhere [5]. Therefore, it has become an essential and challenging issue to place students in a series of designed lessons that combine both real-world and digital-world learning resources [5], [6]. Bloom's taxonomy subdivides the academic skills that students might need into six different categories, listed below [7].

- Basic knowledge: memorizing facts, figures, and basic processes.

- Secondary comprehension: understanding and illustrating the facts.

- Application: generalizing the facts to other contexts and situations.

- Analysis: understanding why the facts are the way they are; breaking problems down.

- Synthesis: making connections between different elements on one's own.

- Evaluation: critically using one's knowledge to ascertain the quality of information [7], [8].

There is practically no comprehensive research in Latvia on the impact of the use of mobile technologies on the physics learning process and the development of academic skills. The study "Challenges and Opportunities for Implementing an Innovative School System Structure" conducted by Microsoft Latvia and Laboratory of Analytical Research and Strategies showed that, if technologies are used purposefully, they offer vast stimulates the development of the process [9]. However, the lack of appropriate teaching materials in the Latvian language is a significant obstacle in the use of technology during lessons, as the preparation of such materials by the teachers, themselves requires both a high level of competence and a considerable time investment [9], [10]. This means that the teachers of physics often do not have sufficient methodological support and practice in the purposeful use of mobile technologies in the teaching process. This necessitates the improvement and development of appropriate methodological materials, considering the problems identified in practice. In Europe and the rest of the world, many comprehensive studies have been carried out on the use of information technology in the learning process, including the use of mobile technologies [11], [12], [13]. One of the conclusions of the researchers is that the use of technologies for the development of skills necessary for young people when entering the 21st-century job market requires not only investment in technology acquisition, but also coordination of the subject content and its teaching methodology. Schoolnet, a network of European Ministries of Education, has compiled the results of 17 studies carried out in various European countries in recent years to determine the impact of technology-based learning on the students' academic achievement levels [14]. Unfortunately, as the Ministry of Education of Latvia is involved in this organization, the report does not reflect the research carried out in Latvia.

\section{Tools and methods}

The research was conducted using surveys, external lesson observations, and focus group discussions for the analysis of the professional development needs of physics teachers. The methods used in the development of support materials were an analysis of scientific and educational literature. The methods used for the pilot study of the educational materials were piloting of materials in the study process and professional development classes, assessment of teachers according to a unified methodology, evaluation by experts, external lesson observations. A survey of physics teachers was carried out in order to determine what aspects of professional development they would be interested in. The present study was based on the quantitative research methodology. The data collected for quantitative research using questionnaires requires special care because it is not enough to obtain responses on the issues of interest; it is also crucial to perform a proper statistical analysis to validate the results (using SPSS Statistics 19). The total number of participants (3764 students and 87 physics teachers) was deemed high enough to draw objective conclusions. The support materials were developed and piloted for the teachers training courses in Riga State Gymnasium No. 3 and Education and Information Services of Riga City (RIIMC) during the school years 2015/2016 and 2016/2017.

\subsection{Mobile technologies resources in the teaching/learning process}

When deciding to use mobile technologies in teaching physics, the teacher should be sure that this is the most effective tool for a particular situation. For example, when studying the working principles of temperature measuring instruments, a student, having watched the demonstration, should conclude what process underlies its operation. The teacher should be able to determine whether the students understand the working principles of the measuring instruments, such as making measurements with a liquid thermometer or a temperature 
sensor. When equipping schools with modern technologies, the primary challenge for the teacher is to learn the technical aspects of their use, as well as and how to use them effectively in the physics learning process. In order to deepen the understanding of the physical processes in nature and technology, students should see these processes and should be able to analyze their manifestation, both by directly observing the procedures and by indirectly analyzing the obtained data [14]. Several physical processes in nature and technology are demonstrated by the teacher in the physics classroom where students are exploring them using various "classical" demonstration tools and devices.

By implementing Mobile technologies (smartphones, tablets, mobile applications, sensors, data storage devices, data cameras) into the physics teaching/learning process, it is possible to demonstrate and study various fast and invisible real processes, for example, to obtain a sound wave recording with a microphone sensor, to measure the quantity of the electric charge on the surface of the electrified bodies with an electric charge sensor. Furthermore, it is possible to perform a research without human presence by recording data over a more extended period of time, for example, by using temperature sensors to analyse the water cooling process in containers made of different materials, or to determine how humidity levels change in the room during a 24 hour cycle by using humidity sensors. The use of various mobile technology resources offers a great variety of possibilities (see Table1).

Table 1. The different mobile technologies resources in the teaching/learning process.

Teaching/Learning process elements
Organizing an interactive learning.
Studying physical processes in nature and
technology, recording changes in the
characteristics of these processes and presenting
them graphically.

Demonstrating devices for detailed experiments to the entire audience simultaneously.

Demonstrating and simulating physical processes.

Providing access to a wide variety of resources.

Processing the data - both for calculations, for the visualization of results and for modeling processes.
Tools and resources

Voting devices with appropriate software

Interactive projector

Mobile applications

Wireless tablet, etc

Sensors
Data collectors \&loggers
Mobile applications
Data camera
Web camera
Smartphones
Tablets
Data collectors \&loggers
Mobile applications
Simulations and Animations
Virtual labs
Internet
Bluetooth
Mobile applications
MS Excel

Sensors and mobile data collectors, smartphones and mobile applications in the physics teaching/learning process make it possible to automatically record and store data obtained in different processes, as well as use sensor-compliant software to process and analyze such data. The use of sensors and data storage devices with computers, smartphones and mobile applications in the learning process is given the name of MBL (microcomputer-based laboratory) [15], [17] or sensors computer lab. By working purposefully in the computer lab, students develop and deepen their understanding of physical concepts and processes, gaining information about the characteristics of the processes and their changes - both numerical data and graphical characteristics change [15]. Moreover, students also gain experience in research work. They learn the way scientists work.

As data registration takes place automatically, there is extra time in the learning process when students can ask questions, predict the process and results of the process under different conditions, analyze the obtained 
data, draw conclusions and ask new questions. In doing so, they develop and improve their problem-solving skills [16], as well as skills for plotting and analyzing graphics [15], [18], [19]. For example, by using a motion sensor or mobile application, students get a graph with coordinates of a moving object and a speedtime graph online, observing a moving object or analyzing the given graphs, repeating the movement shown in the graph. The sensor software or a mobile application features that ensure graphical representation of the change of the characteristics in the observed process online are mentioned as the most significant benefit of the technology-based learning process compared to the traditional way of work. [15], [20], [21]. Students working in a sensor computer lab or mobile lab can follow the ongoing process, and the graphical representation of its characteristics change at the same time, thus clearly linking the reality with the mathematical description of the process. The sensor speed and ability to measure and record data with multiple sensors, in turn, allow students to take more measurements during one lesson by testing their hypotheses in practice, as well as changing the experimental conditions, to get a change in characteristics in new conditions. The more students' assumptions are tested experimentally, the deeper understanding of the process they get [22], [23], [24]. Sensors, data collectors and smartphones are only digital devices, and while researchers point out the impact of their purposeful use on student achievement, this impact, however, depends on the careful organization of the learning process by the teacher: whether the learning process is organized in such a way as to promote testing of new ideas, restructuring of previous knowledge and establishing a link to the new experience [24], [25].

\subsection{The stages of the research and the novelty of the research}

\section{Stage 1:}

Analysis of the current situation and trends in the use of Mobile technology-based learning process in physics, problem identification, research ideas, research goals and assignment of tasks, analysis of scientific literature, elaboration of theoretical substantiation of the research.

\section{Stage 2:}

The study of the needs of professional physics teacher training, development of support materials and piloting of results for purposeful mobile technology integration in the physics learning process; development and piloting of professional development classes for further education courses for secondary school physics teachers on the purposeful use of mobile technologies in the physics learning process.

The novelty of the research:

Advantages and disadvantages of the use of Mobile technologies (sensors, data collectors, mobile applications) in the context of teaching physics content in Latvian schools were examined and described. Recommendations for teachers' professional development were developed, and professional development materials were piloted.

\section{Results and discussion}

A new trend can be observed in education: the focus is no longer on how to acquire the technical skills of using mobile technology, but on the methodological skills of using mobile technology, which requires continuous support from the school administration and a significant amount of time to invest directly in developing the teachers' professional competence, which in turn can be realized with appropriate learning resources. When using technologies in order to develop young people's skills necessary for the job market, it is not enough to invest in the acquisition of technology; the use of technologies should also be aligned with both the specific content of the subject and its teaching methodology. It is also necessary to take into account that their integration in the learning process takes time - so that the teacher is able to acquire the opportunities offered by technology-based teaching and learning both technically and methodically. The time necessary for that will be different for young teachers who grew up in the technological age - they will need less time to learn to use the software, while experienced teachers most probably will have to invest more time into developing their skills. When using Mobile technologies, the teacher should organize an active learning process, as in the active learning process, students' learning achievements are more important than in the traditional learning process [26], [27].

\subsection{The frequency of use of mobile technologies in the learning process}

Teachers of physics do not have sufficient methodological support and practice in the purposeful use of Mobile technologies in the learning process. The frequency of technology use and purposefulness in the learning process are often discussed (see Figure 1 and Figure 2). 


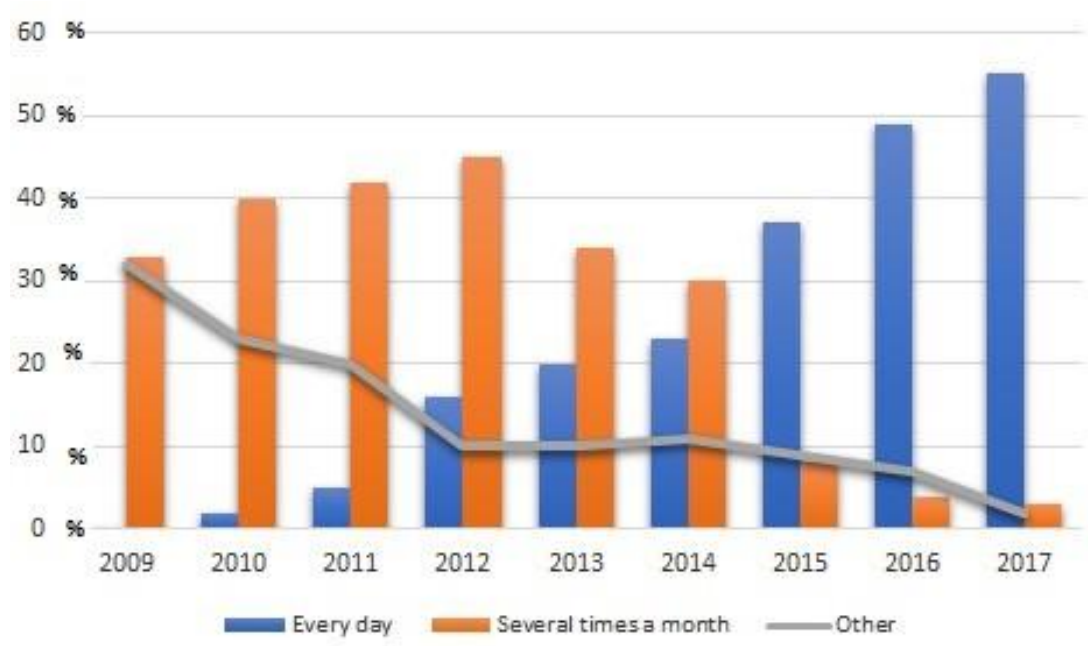

Figure 1. The frequency of use of mobile technologies in the teaching process (teachers' answers, \%).

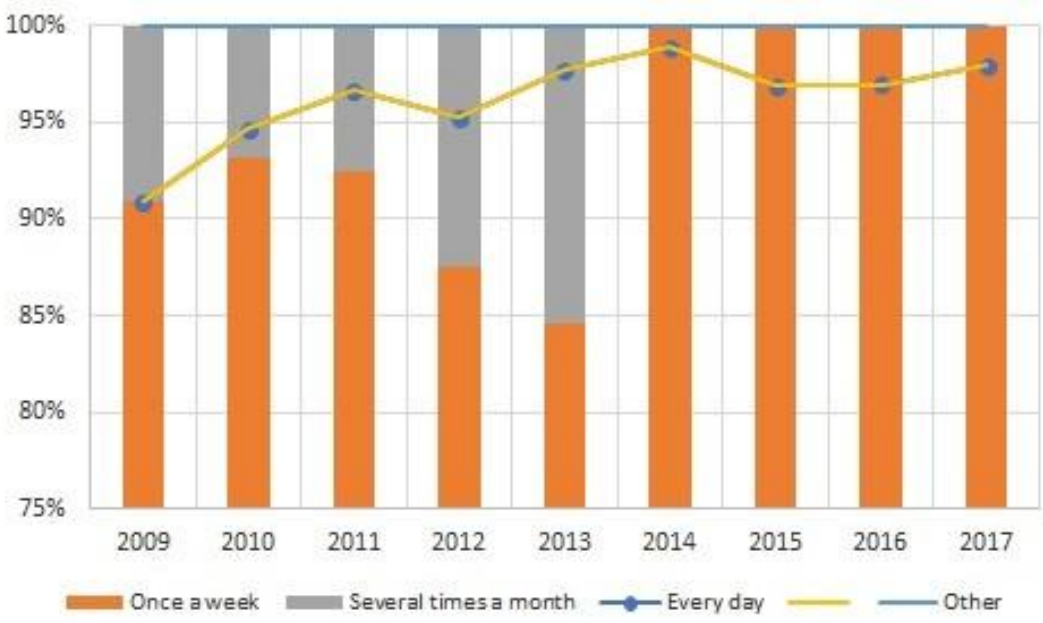

Figure 2. The frequency of use of mobile technologies in the learning process (students' answers, \%).

Teachers' responses to the development of their and students' mobile technology skills:

During the last two years, my skills in using Mobile technologies in the learning process have improved.

I use Mobile technologies purposefully in my lessons.

By comparing the answers provided by the school administration and the teachers, it can be concluded that the teachers appreciate the purposeful use of Mobile technologies in the lesson (96.5\%), while the school administration's responses vary (55.2\%). The difference can be explained by the fact that teachers feel confident about the purposes for which they use mobile technology in lessons. Moreover, the teachers also believe that they are using Mobile technologies purposefully (75.23\%), while the administration estimates that the purposeful use of mobile technologies takes place in fewer cases (37.4\%). These results show a different understanding of teachers and school administration regarding the purposeful use of mobile technologies in the learning process.

The most widely used tools are sensors, data collectors, data loggers, and smartphones with relevant applications, so attention is paid to these technologies (see Figure 3). 


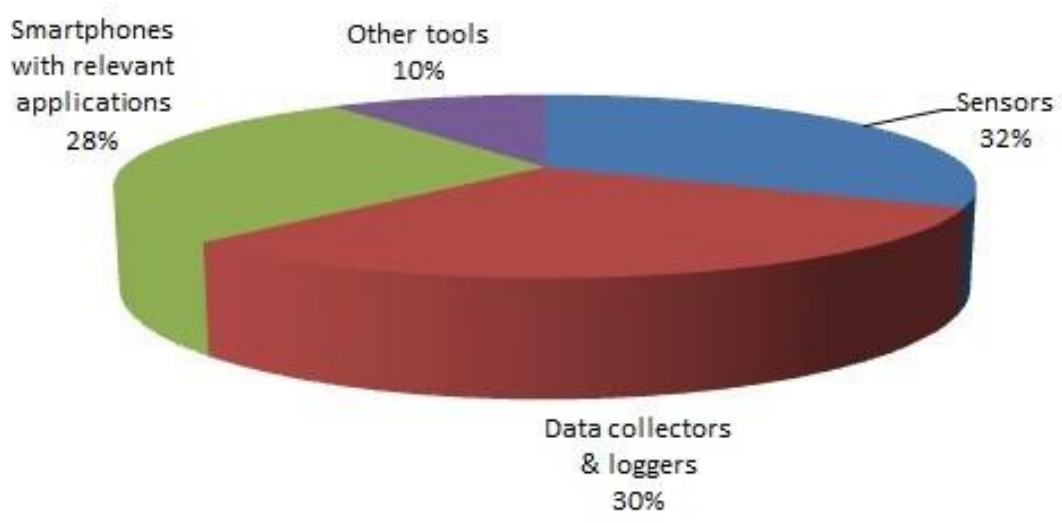

Figure 3. The most widely used tools (\%) [28].

\subsection{Mobile technologies in teachers' working environment}

The availability of Mobile technologies (smartphones, tablets, sensors, data collectors, data loggers, and other devices) in the classroom does not automatically guarantee results. Even more important is teachers' accumulated experience in working with technology, including Mobile technologies and their software, and the confidence of what students can do with the Mobile technologies in the learning process. If the teachers are not sure, they will not offer their students the opportunity to work with the Mobile devices or will not be convinced that the physical processes can also be studied with these devices. This can give the impression that Mobile devices can be used in a lesson as some sort of toys. Thus, the most important role for the purposeful introduction of Mobile technologies into the physics learning process belongs to teachers who should offer and be able to explain the benefits of Mobile technologies to their students. This should be taken into account when developing professional development courses for teachers. Having evaluated each teaching material, teachers introduced their comments on the problems they observed, regarding the necessary improvements and corrections in wording. The most important section for the development of the created support materials is the direct comments, as in these sections teachers indicated which descriptions needed improvement. The use of Mobile technologies in the learning process increases each year and is positively evaluated by students and teachers. The several surveys were conducted between 2009 and 2017 (3764 students' (17-19 age range) and 87 physics teachers' questionnaires on physics lessons). In the last two years, Mobile technologies (see Figure 4) have become the most often used devices in physics classes with teachers making use of relevant applications.

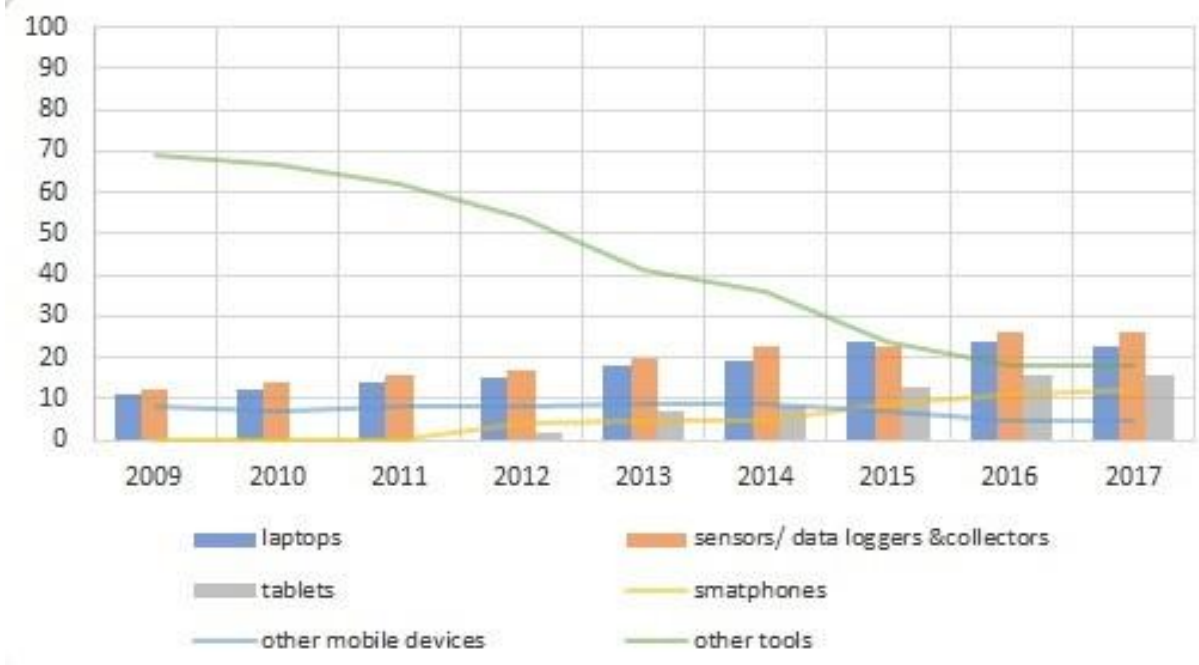

Figure 4. Mobile Technologies in Teachers' Working Environment, \% [au-thor's research data] 


\subsection{Criteria and indicators for evaluation of teachers support materials}

Technical problems were mentioned as the most common issues with using Mobile technologies during lessons, with teachers requiring help from ICT teachers or students since they do not have relevant skills. Teachers also point out that it takes time to learn to use the equipment available in the school and plan a lesson for the most efficient use of Mobile devices in the class. One of the most frequent answers to the question of what help would be needed to effectively use the available Mobile technologies in the learning process is more materials for Mobile technologies, methodological support if necessary, professional development courses. Having evaluated each teaching material, teachers introduced their comments on the problems they observed in an electronic environment, regarding the necessary improvements and corrections in wording. Criteria and Indicators for the Evaluation of teachers support materials and descriptions (Table 2).

Table 2. Criteria and Indicators for Evaluation of teachers support materials.

\begin{tabular}{|c|c|}
\hline Criteria & Indicators (evidence) \\
\hline Overall technical quality. & $\begin{array}{l}\text { The material is well structured, clear. } \\
\text { The amount and layout of the included information is } \\
\text { appropriate, economical. }\end{array}$ \\
\hline \multirow{5}{*}{$\begin{array}{l}\text { The set of activities is } \\
\text { methodologically thought out, } \\
\text { systematic, correctly designed. }\end{array}$} & $\begin{array}{l}\text { Gradual and continuous acquisition of research skills is } \\
\text { incorporated. }\end{array}$ \\
\hline & Assessment options are clear. \\
\hline & $\begin{array}{l}\text { The included methodological comments are essential, } \\
\text { ensuring a clear procedure. }\end{array}$ \\
\hline & $\begin{array}{l}\text { Tasks and rubrics are clear, unambiguous, and easy to } \\
\text { understand. }\end{array}$ \\
\hline & $\begin{array}{l}\text { The correct use of academic and pedagogical terms is } \\
\text { observed. }\end{array}$ \\
\hline \multirow[b]{2}{*}{$\begin{array}{l}\text { The materials are } \\
\text { methodologically correct. }\end{array}$} & $\begin{array}{l}\text { Corresponds to the purpose of the material. } \\
\text { Individual parts of the activity are consistent and } \\
\text { interconnected. }\end{array}$ \\
\hline & $\begin{array}{l}\text { The activity is safe for the students' health and the } \\
\text { environment; it sets out the safety measures to be followed. } \\
\text { The equipment offered in the activity corresponds to the } \\
\text { modern learning process, it is available and economical. }\end{array}$ \\
\hline
\end{tabular}

\section{Conclusion}

Mobile technologies are constantly and rapidly evolving, and there is practically no social domain where they would not be used, including education. Thus, the acquisition of mobile technology skills is an integral part of the learning process in a modern school. Education experts are now placing the emphasis on not only integrating mobile technologies into the teaching/ learning process but also on improving the efficiency of the learning process for both teachers and students. The use of different mobile technology resources offers a lot of possibilities:

- $\quad$ organizing an interactive learning process;

- $\quad$ studying physical processes in nature and technology, recording changes in the characteristics of these processes and presenting them graphically;

- $\quad$ demonstrating devices for detailed experiments to the entire audience simultaneously;

- $\quad$ demonstrating and simulating physical processes;

- $\quad$ providing access to a wide variety of resources;

- $\quad$ processing the data - both for calculations, for the visualization of results and for modeling processes.

When deciding to use mobile technologies in the physics learning process, the teacher should be sure that this is the most effective tool in a particular situation. The current challenge is to apply these general principles to a particular subject, to specific content and to a certain level of education. 
Physics teachers were surveyed in order to find out what they would like to add to their professional development. The results showed that in most cases teachers pointed out eliminating the stress when working with new technologies and mentioned learning how to perform demonstrations and laboratory work using Mobiles technologies. The most frequent answer to the question of what help would be needed to effectively use the available information technologies in the learning process: more materials in Latvian, methodological support, professional development courses.

The school administration noted students' successful use of mobile technologies and an increase in students' motivation:

Students skilfully use the mobile application during lessons and doing their homework.

The use of Mobile technologies creates a willingness to work and often helps to understand the importance of learning content.

Based on the results of the research, develop recommendations for professional development of physics teachers for purposeful use of mobile technologies in teaching physics. A program has been developed and 24 x $2=48$ hour courses for teachers ( 2 modules), 8 seminars, 6 workshops and 9 master classes conducted.

\section{Acknowledgements}

Special thanks to the Austris Cabelis (National Centre for Education) for help with a database, Vita Petersone, Rota Nabele Sneidere and Andris Priekulis (Riga State Gymnasium Nr 3) for organizing teachers training courses.

\section{References}

[1] A. Gorbunovs, A. Kapenieks, K. Kapenieks, B. Zuga, R. Gulbis, I. Kudina, "Conceptual Design and Model of the Feedback Solutions in the Adaptive Integrated Technological Systems," in Proceedings of the 11th International Scientific Conference "eLearning and Software for Education (eLSE-2015)", Bucharest, 2015, vol. 1, pp. 210-215.

[2] A.Cabelis et al., "Content and requirements for learning. Physics" in Latvian Language "Mācību saturs un prasības tā apguvei. Fizika," Materials for teachers, VISC, 2018, pp. 33-34.

[3] Ministry of Education and Science of Latvia, "Proposals to provide conceptually new competency-based education for teachers in Latvia" (in Latvian language "Priekšlikumi konceptuāli jaunas kompetencēs balstītas izglīîibas prasībām atbilstošas skolotāju izglītības nodrošināšanai Latvijā "), Informative report IZM 2017 pp. 20-22. [Internet], November 14, 2017 [cited 22.12.2018], available from: http://www.izm.gov.lv/images/izglitiba_visp/IZMinfozinoj_14112017_skolotaju_izglitiba.pdf.

[4] EADSNE, "Information and Communication Technology for Inclusion Achievements and Opportunities in European Countries, European Agency for Development in Special Needs Education" (in Latvian Language "Informācijas un komunikācijas tehnologija iekḷaušanai Sasniegumi un iespējas Eiropas valstīs, Eiropas speciālās izglītības attīstības aǵentūra"), Informative report European Agency for Development in Special Needs Education 2013 pp. 8-12.

[5] Council of the European Union, "Directive (EU) 2016/2102 of the European Parliament and of the Council of 26 October 2016 on the accessibility of the websites and mobile applications of public sector bodies," Official Journal of the European Union, Brussels [Internet], December 2, 2016 [cited 20.12.2018], available from: http://eur-lex.europa.eu/legalcontent/EN/TXT/?uri=uriserv:OJ.L_.2016.327.01.0001.01.ENG\&toc=OJ:L:2016:327:TOC.

[6] J. Miller-Young \& J. Boman, "Uncovering ways of thinking, practicing and being through decoding across disciplines," in Proceedings New Directions for Teaching and Learning, 2017, pp. 148.

[7] B. S. Bloom, M. D. Engelhart, E. J. Furst, W. H. Hill, D. R. Krathwohl, "Taxonomy of educational objectives: The classification of educational goals." Handbook I: Cognitive domain. New York: David McKay Company, 1956, pp. 68-71.

[8] H. Hoy, A. Woolfolk, "Educational psychology." Boston: Pearson/Allyn and Bacon, 2007, pp. 530-531.

[9] Laboratory of Analytical and Strategic Studies, "Challenges and Opportunities for Implementing an Innovative School System Structure" (in Latvian language "Inovatīvas skolu sistēmas struktūras īstenošanas izaicinājumi un iespējas"), Informative report, Microsoft Latvia, 2010, pp. 8- 13. [Internet], 
published May 19, 2015 [cited 22.12.2018], available from: https://docslide.net/documents/inovativasskolu-sistemas-strukturas-istenosanas-izaicinajumi-un-iespejas-2010.html.

[10] Daugavpils City Council, "Concept of Development of the Network of General Education Institutions for 2013 - 2017" (in Latvian language "Vispārējās izglītības iestāžu tīkla attīstības koncepcija 2013. 2017.gadam”), Report of Daugavpils City Council 2013, pp. 5-11, 2013.

[11] C. Lai, Q. Wang, J. Lei, "What factors predict undergraduate students' use of technology for learning? ," Journal Computers \& Education, vol. 59, no. 2, pp. 569-579, 2012.

[12] Ministry of Education and Science of Latvia, "Prestige of Teachers in Latvia in the Context of Lifelong Learning" in Latvian Language "Skolotāju prestižs Latvijā mūžizglītības kontekstā", Report European Commission, EPALE 2017 pp. 6- 7. [Internet], May 29, 2017 [cited 20.12.2018], available from: https://ec.europa.eu/epale/lv/blog/skolotaju-prestizs-latvija-muzizglitibas-konteksta.

[13] Y. TingSung, K. Chang, T. Chien, "The ef-fects of integrating mobile devices with teaching and learning on students' learning performance: A meta-analysis and re-search synthesis," Journal Computers \& Education, vol. 94, pp. 252-275, 2016.

[14] European Schoolnet's 2017 Annual Report, European Schoolnet (EUN Partnership AIBSL) Brussels, Belgium 2017. [Internet], Jule 232018 [cited 20.12.2018], available from: http://www.eun.org/documents/411753/1866395/EUN+Annual+Report+2017_WEB_DEF.pdf/eaac6571c4c7-4ae4-a60c-a853e38f213e.

[15] D. W. Russell, K. B. Lucas, and C. J. McRobbie, "Role of the microcumputer-based laboratory display in supporting the construction of new understandings in thermal physics" Journal of Research in Science Teaching, vol. 4, no. 41, pp. 165-185, 2004.

[16] J. Kapenieks, "Educational Action Research to Achieve the Essential Competencies of the Future," Journal of Teacher Ed-ucation for Sustainability, vol. 18, pp. 95-111, 2016.

[17] J. R. Mokros, R. F. Tinker, "The impact of mi-crocomputer-based labs on children`s ability to interpret graphs," Journal of Research in Science Teaching, vol. 24, no. 4, pp. 369-383, 1987.

[18] R. Cortez, M. Nussbaum, R. Santelices, P. Rodriguez, G. Zurita, M. Correa, and R. Cautivo, "Teaching science with mobile computer supported collaborative learning (MCSCL)," in Proceedings of Wireless and Mobile Technologies in Education Conference. WMTE 2004. IEEE Learning Technology Task Force, IEEE Computer Society, JungLi, Taiwan, pp. 67-74, 2004.

[19] G. Zurita, M. Nusbaum, "A Constructivist mobile learning environment supported by a wireless handheld network," Journal of Computer Assisted learning, vol. 20, no. 4, pp. 235, 2004.

[20] L. Echegaray, C. Periafiel, M. Ronco, "The influence of media contents about health in the construction of the discourse about the body in young adults and teenagers," in Proceedings of the Second International Conference on Technological Ecosystems for Enhancing Multiculturality Salamanca, Spain 2014 pp. 321- 326. [Internet], 2014 [cited 22.12.2018], available from: https://dl.acm.org/citation.cfm?doid=2669711.2669918.

[21] M. J. Ferreira, F. Moreira, C. S. Pereira, "The role of mobile technologies in the teaching/learning process improvement in Portugal, Natercia Durão Univer-sidade Portucalense (Portugal)", Proceedings of ICERI2015 Conference, 16th-18th November 2015, Seville, Spain.

[22] C. D. Cziprok, C. Miron, F. Popescu, "Inquiry-Based earning using mobile physics laboratory - ipad, bluetooth and sensors" Journal eLearning \& Software for Education, vol. 2, pp. 110-115, 2014.

[23] R. Trumper, "The Physics Laboratory - A Historical Over-view and Future Perspectives" Journal Science \& Education, vol. 12, no. 7, pp. 645-670, 2003.

[24] Y. J. Dori, E. Hult, L. Breslow \& J. Belcher, J. "How much have they related? Making unseen concepts seen in a freshman electromagnetism course at MIT," Journal of Science Education and Technology, vol.16, pp 299-323, 2007.

[25] S. Tatili, T. Treska, B. Mero, "How does technology influence on education in nowadays," European center for science education and research ejms european journal of multidisciplinary studis, vol. 1, no. 4, pp. 138-141, 2016.

[26] N. Aharony "Library and information science students' perceptions of m-learning". Journal of Librarianship and Information Science, vol. 46, no. 1, pp. 48-61, 2014. 
[27] Y. Park, "A pedagogical framework for mobile learning: Categorizing educational applications of mobile technologies into four types," The International Review of Research in Open and Distributed Learning, vol. 12, no. 2, pp. 78-102, 2010.

[28] Z. Yan, Y. Dong, V. Niemi, G. Yu, "Exploring trust of mobile applications based on user behaviors: An empirical study," Journal of Applied Social Psychology, vol. 43, no. 3, pp. 638-659, 2013. 